\title{
PENGEMBANGAN SISTEM INFORMASI PENJUALAN IKAN CUPANG BERBASIS WEB DI LABETTA SOLO
}

\author{
Dandung Rahmatdhan ${ }^{[1],}$ Dedi Gunawan ${ }^{[2]}$ \\ Program Studi Informatika \\ Universitas Muhammadiyah Surakarta \\ Surakarta Indonesia \\ $\underline{\text { 19dandung99@gmail.com }}^{[1]} \underline{\text { dedi.gunawan@ums.ac.id }}^{[2]}$
}

\begin{abstract}
Labetta Solo is a seller of ornamental betta fish located at Kepatihan Kulon, Kec. Jebres, Surakarta City, Central Java. The process of sales and transactions are still using the manual transaction model, where customers have to go to the store to see the Betta fish collection to make transactions. In some cases, customers are visiting the Betta fish collection on Labetta Solo social media and doing COD (Cash on Delivery) with the seller for transactions. However, such activities should be limited specifically meeting with other people due to COVID-19 pandemic. Therefore, to address the challenge and increase the sales we design a web-based application so that the Labetta Solo still be able to perform transaction and customers can still buy Betta fish easily. The system is designed using the Waterfall method including analysis, design, coding, testing, implementation. In the implementation process the system is built using MySQL database and PHP CodeIgniter framework as the programming language. Several unique features are also developed to the system such as location map to help customers identify the store location and embed messaging application to facilitate customer communication. To evaluate the system, we conduct several tests such as black box testing and system usability scale. Experimental results show that our system is well performed and meet the user expectation with high usability scale around $75 \%$.
\end{abstract}

Keywords-Betta fish, web, Waterfall, PHP

Abstrak - Labetta Solo merupakan penjual ikan cupang hias yang berlokasi di Kepatihan Kulon, Kec. Jebres, Kota Surakarta. Proses penjualan dan transaksi yang dilakukan masih mengagunkan model transaksi manual yaitu costumer harus ke toko untuk melihat langsung koleksi ikan cupang untuk melakukan transaksi, atau dengan cara melihat koleksi ikan cupang di media social labetta solo untuk kemudian melakukan COD (Cash On Delivery) dengan penjual untuk transaksi. Dengan pembuatan sistem ini nantinya labetta solo tetap dapat berjualan dan costumer tetap dapat membeli ikan cupang dengan mudah. Sistem ini dibuat menggunakan metode Waterfall meliputi analysis, design, coding, testing, implementation menggunakan database $M Y S Q L$ dan $P H P$ Codeigniter sebagai bahasa pemrogramannya. Penjual dapat menjual ikan melalui sistem ini dan terdapat rating atau grade dari kualitas ikan sehingga memudahkan costumer dalam melakukan pemilihan ikan yang akan di beli, sistem ini juga terdapat lokasi dari Labetta Solo untuk memudahkan bagi customer yang ingin berkunjung langsung ke lokasi dan untuk mempermudah komunkasi kepada customer akan tersedia link menuju WahatsApp dari penjual. Berdasarkan hasil pengujian dengan black-box testing menunjukkan bahwa sistem tidak memiliki error, selain itu uji penerimaan user terhadap aplikasi juga tergolong tinggi dengan prosentase sekitar $75 \%$.

\section{Kata Kunci-ikan cupang, web, Waterfall, PHP}

\section{PENDAHULUAN}

Ikan cupang merupakan ikan hias air tawar yang mudah untuk dipelihara dan di budidaya karena jenis ikan ini tidak memerlukan wadah yang besar dan makanan yang cukup mudah di dapat. Ikan hias mempunyai peran penting dalam menambah kesegaran, keindahan dan kesejukan lingkungan melalui jenis, warna, ukuran dan bentuk tubuhnya yang indah dan menarik [1]. Salah satu keistimewaan ikan cupang yaitu memiliki daya tahan tubuh yang kuat yang dapat hidup dengan wadah yang relatif kecil dan kondisi air yang minim oksigen sekalipun. Ikan ini tidak membutuhkan aerator atau gelembung udara seperti yang digunakan pada ikan hias lain, sehingga ikan ini banyak di sukai semua kalangan masyarakat dari anak kecil hingga orang dewasa, selain itu ikan ini banyak digemari karena keindahan bentuk sirip dan warnanya. Ikan cupang memiliki jenis yang banyak mulai Half-moon, Plakat, Giant dan sebagainya, serta jenis tersebut masih mempunyai jenis lagi seperti multicolor, blue rim, avatar dan masih banyak lagi

Perkembangan teknologi yang semakin cepat membuat para penjual harus mengikuti perkembangan teknologi dengan cara online, penjualan online atau e-commerce sudah menjadi tren saat ini, karena pandemic covid-19 membuat para penjual tetap bisa mendapatkan penghasilan melalui platform $e$ commerce [2]. Sebuah perusahaan pemasaran e-bisnis, memperkirakan penjualan e-commerce ritel di seluruh dunia akan meningkat dari $\$ 2,29$ triliun pada tahun 2017 menjadi $\$ 4,48$ triliun pada akhir tahun 2021 [3], maka dari itu bisnis jual ikan ini bisa kita jadikan bisnis online agar bisnis ikan ini lebih meningkat dan dapat mencapai pasar global [4][5]. Tak hanya lewat platform e-commerce penjual juga banyak menggunakan media social sebagai tempat berjualan maupun promosi salah satunya melalui media social seperti Instagram, Facebook dan lain lain [6], dengan cara ini pembeli dapat melihat barang yang ditawarkan, salah satu penjual yang 
menggunakan media social sebagai tempat berjualan tersebut adalah Labetta Solo.

Secar umum, untuk mendapatkan ikan cupang biasanya masyarakat pergi ke penjual ikan di pasar hewan atau ke toko khusus ikan hias. Namun, dimasa pandemi saat ini banyak calon pembeli yang merasakan kesuliatan untuk membeli ikan cupang karena banyak penjual yang tutup dan dibatasinya aktifitas masyarakat di keluar rumah [7]. Labetta solo pada beberapa bulan ini khususnya dimasa pandemi mengalami kesulitan menjual ikan cupang sehingga pemilik memilih menggunakan media social seperti group jual beli di facebook. Namun sangat disayangkan beberapa iklan yang diposting oleh Labetta solo dihapus oleh admin group karena dianggap tidak memenuhi kriteria dari sosial media dikarenakan adanya orang yang berbuat iseng melaporkan postingan tersebut. Pemilik Labetta solo sebetulnya juga sudah bergabung dan memasang iklan diberbagai platform e-commerce yang populer di Indonesia akan tetapi muncul masalah lain yaitu repotnya melakukan rekapitulasi penjualan dan perhitungan laba rugi karena tidak ada laporan khusus terkait hal ini. Dari berbagai permasalahan tesebut maka solusi yang paling memungkinkan adalah dibuatnya sistem informasi penjualan ikan cupang berbasis web. Dengan adanya teknologi maka akan membantu dalam proses penjualan dan promosi serta mempermudah dalam penyelesaian pekerjaan [8].

Sistem tersebut nantinya akan dikembangkan menggunakan metode waterfall meliputi Requirements Analysis, Design, Implementation, Testing, Maintenance system, system ini akan dibangun menggunakan tool seperti $X A M P P$, database $M y S Q L$ dan $P H P$ sebagai bahasa pemrograman [9], penggunaan bahasa pemrograman karena PHP merupakan bahasa pemrograman yang tidak berbayar (open source) yang dapat digunakan oleh siapa saja. PHP juga dapat terintegrasi dengan baik pada database $M y S Q L$, aplikasi web berbasis PHP tergolong aman dibandingkan dengan aplikasi web yang dikembangkan menggunakan bahasa pemrograman lain. Sistem yang dikembangkan berbeda dengan sistem sejenis yang sudah dikembangkan sebelumnya [10] dimana pada sistem yang akan terdapat fitur ongkos pengiriman sehingga pembeli bisa memperkiraan total harga yang harus dibayar.

Diterapkanya system informasi penjualan ikan cupang berbasis web di labetta solo diharapkan dapat menarik minta pembeli dan memperluas jangkauan pasar mereka [10], dengan kemudahan proses pembelian menggunakan system ini sehingga dapat meningkatkan penjualan ikan di labetta solo, sistem pembelian online memudahkan pembeli tanpa harus keluar rumah. sistem ini akan dibuat sesuai kebutuhan dari Labetta Solo.

\section{METODE}

Metode yang diterapkan pada pengembangan sistem informasi ini adalah dengan metode pengembangan perangkat lunak waterfall [11]. Metode waterfall merupakan model pengembangan sistem informasi yang sederhana, sistematik dan berurutan serta mudah untuk diikuti [12] sehingga sangat tepat untuk diadopsi dalam pengembangan sistem informasi yang tidak terlalu kompleks. Metode Waterfall memiliki tahapan-tahapan sebagai berikut :

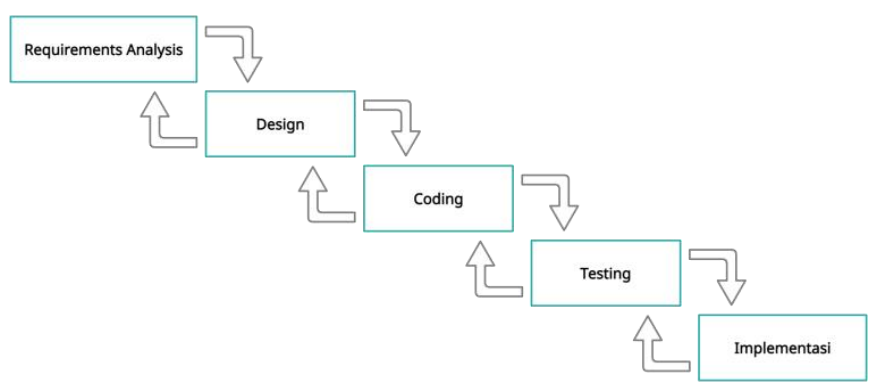

Gambar 1. Waterfall

\subsection{Requirements Analysis}

Proses requirements analysis yaitu mengumpulkan datadata mengenai sistem informasi penjualan ikan cupang, dalam pengumpulan data ini dapat dilakukan dengan cara wawancara kepada pemilik usaha untuk mengetahui proses atau cara yang digunakan oleh pemilik untuk menjual ikan cupang, observasi maupun penelitian secara langsung untuk mendapatkan data atau informasi yang lebih akurat, dalam tahap analisis nantinya akan didapatkan informasi mengenai penjualan ikan cupang, agar nantinya software yang dibuat dapat berjalan sesuai yang diharapkan. Dari proses wawancara didapatkan hasil bahwa terdapat 2 jenis user yaitu Administrator dan Costumer.

2.1.1 Administrator memiliki user accessibility yaitu : sistem login, mengelola data transaksi, cek konfirmasi pembayaran, mengelola pengiriman barang, mengelola laporan transaksi, mengelola data produk, dan mengelola data user, mengelola kebutuhan sistem.

2.1.2 Customer memiliki user accessibility yaitu : menampilkan dan menambahkan produk ke keranjang, sistem registrasi dan login, melakukan transaksi, mengelola user account, konfirmasi pembayaran, melakikan ulasan, menambahkan favorite.

\subsection{Design}

Tahapan ini berfokus pada pembentukan arsitektur keseluruhan dari sistem yang akan dibuat dapat berupa struktur data, perancangan interface, perancangan fungsi internal maupun eksternal [13]. Pada tahap ini peneliti menggambarkan diagram yaitu Use Case, Activity Diagram, ERD (Entity Relationship Diagram) dan User Interface.

\subsubsection{Use Case}

Use case merupakan gambaran dari user dan sistem yang mendeskripsikan sebuah interaksi dari satu user atau lebih dari sistem yang akan dibuat, di dalam sebuah use case juga dapat diketahui interaksi apa aja yang aka dijalankan oleh sistem yang dibuat [14]. 


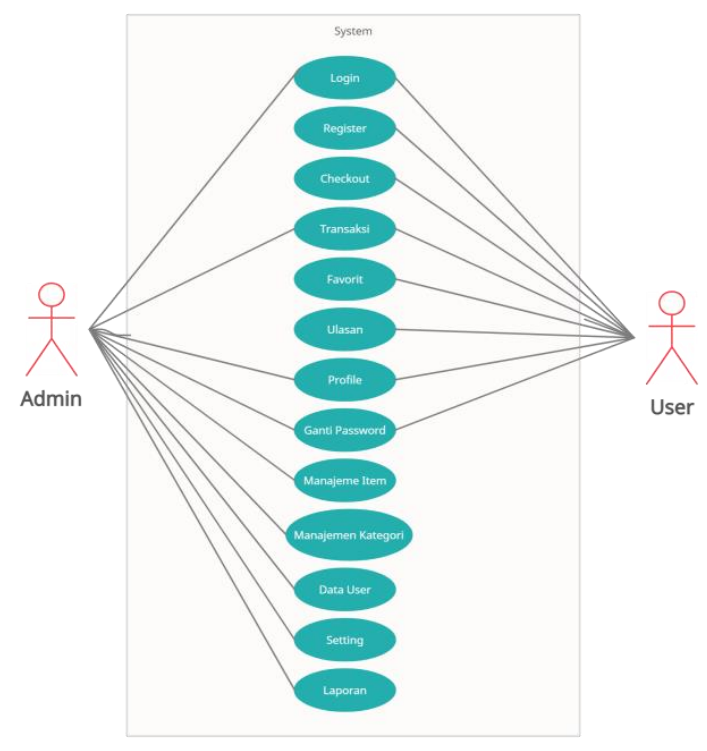

Gambar 2. Use Case

\subsubsection{Activity Diagram}

Activity diagram dibuat untuk menjelaskan proses yang dilakukan antara interaksi user pada sistem dimulai dari awal sampai akhir proses, Activity diagram juga menggambarkan jalanya proses sebuah sistem secara gari besar. Gambar 3 merupakan activity diagram Admin. Gambar 4 merupakan Activity Diagram User atau pengguna.

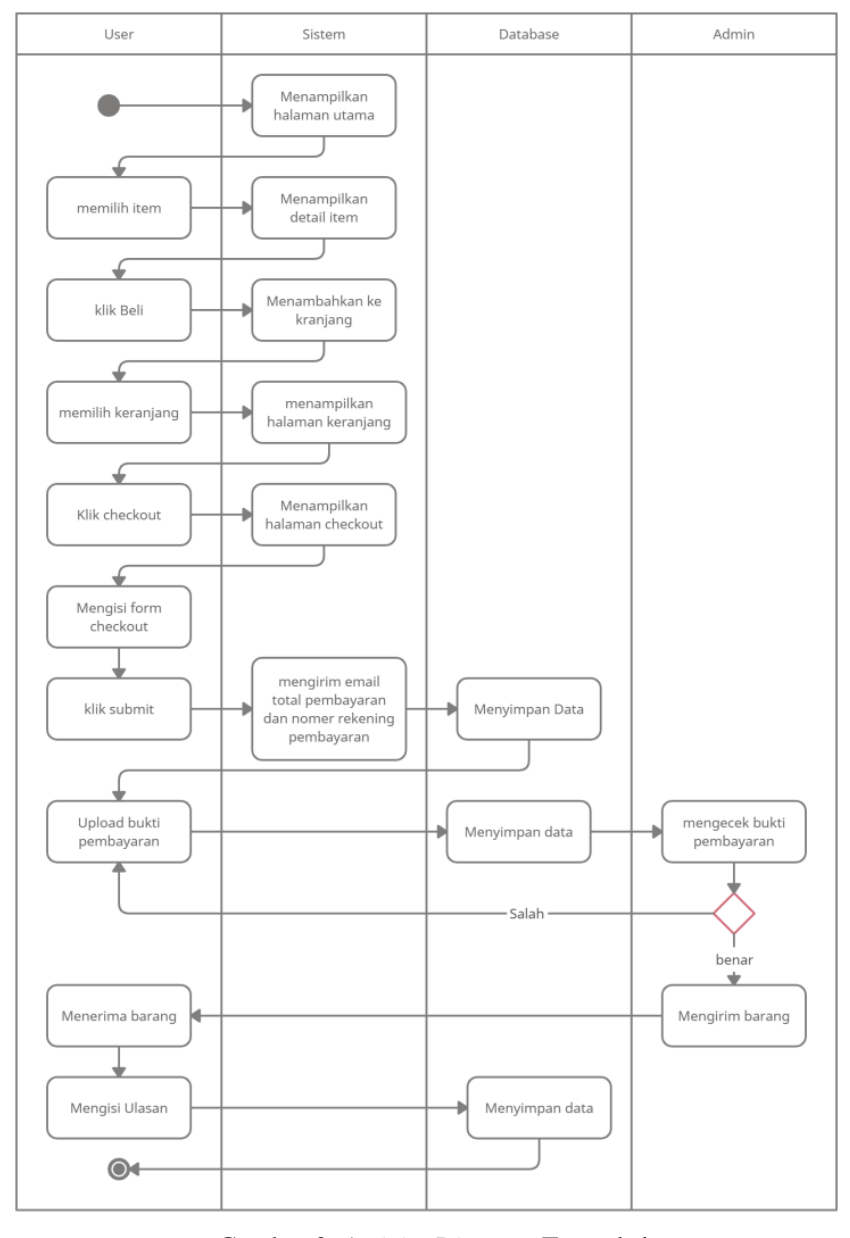

Gambar 3. Activity Diagram Transaksi

Gambar 3. Ketika user berhasil menambahkani item ke keranjang lalu mengklik checkout maka akan masuk ke halaman checkout, akan muncul total pembayaran setelah user mengisi alamat pengiriman lalu klik submit, maka akan masuk email invoice pembayaran dan nomer rekening pembayaran, kemudian user mengupload bukti prmbayaran di halaman upload bukti, kemudian admin akan mengkonfirmasi pembayran dan memproses pengiriman barang jika pembayaran valid, administrator akan mengirimkan bukti pengiriman yang dapat dilihat di detail transaksi user, user megkonfirmasi barang telah diterima jika barang sudah sampai kemudian mengisi ulasan barang. 


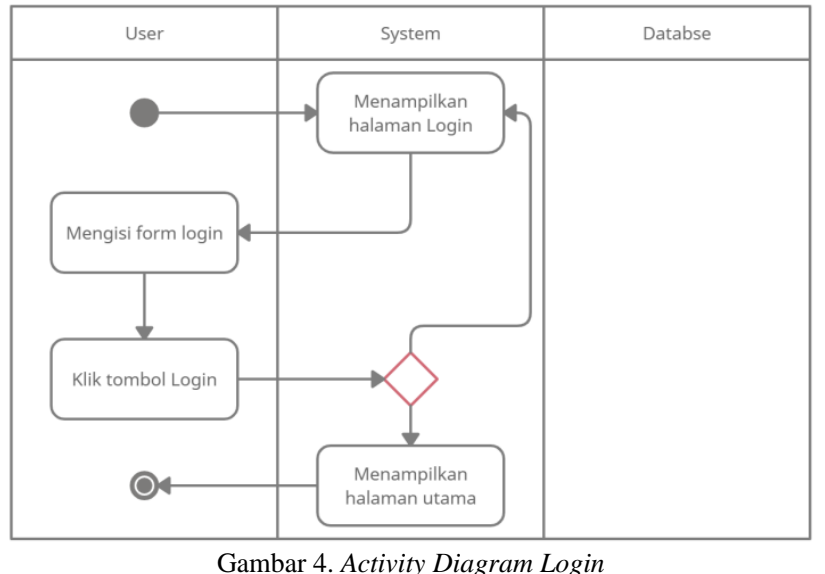

Gambar 4. Merespon permintaan User dengan menampilkan halaman Login kemudian User menginputkan Email dan Password lalu klik tombol 'Login', maka sistem akan melakukan otentifikasi dengan database. Jika berhasil maka akan diarahkan langsung ke halaman Utama atau Dashboard Administrator dan jika gagal maka akan tetap berada di halaman Login.

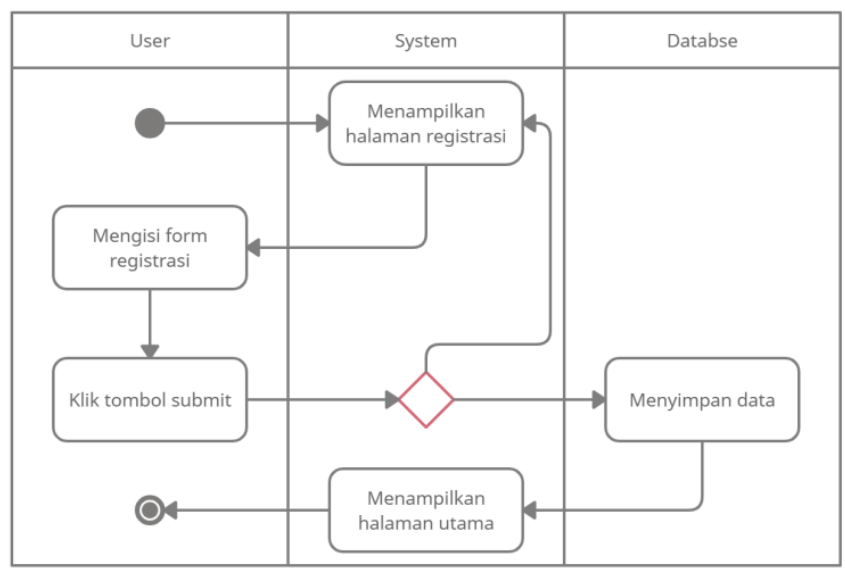

Gambar 5. Activity Diagram Register

Gambar 5. Merespon permintaan User dengan menampilkan halaman Registrasi kemudian User menginputkan form registrasi kemudian klik 'Submit', maka sistem akan melakukan otentifikasi dengan database. Jika berhasil maka akan diarahkan langsung ke halaman Login dan jika gagal maka akan tetap berada di halaman Registrasi serta muncul pesan keselahan pada inputan $u$ ser.

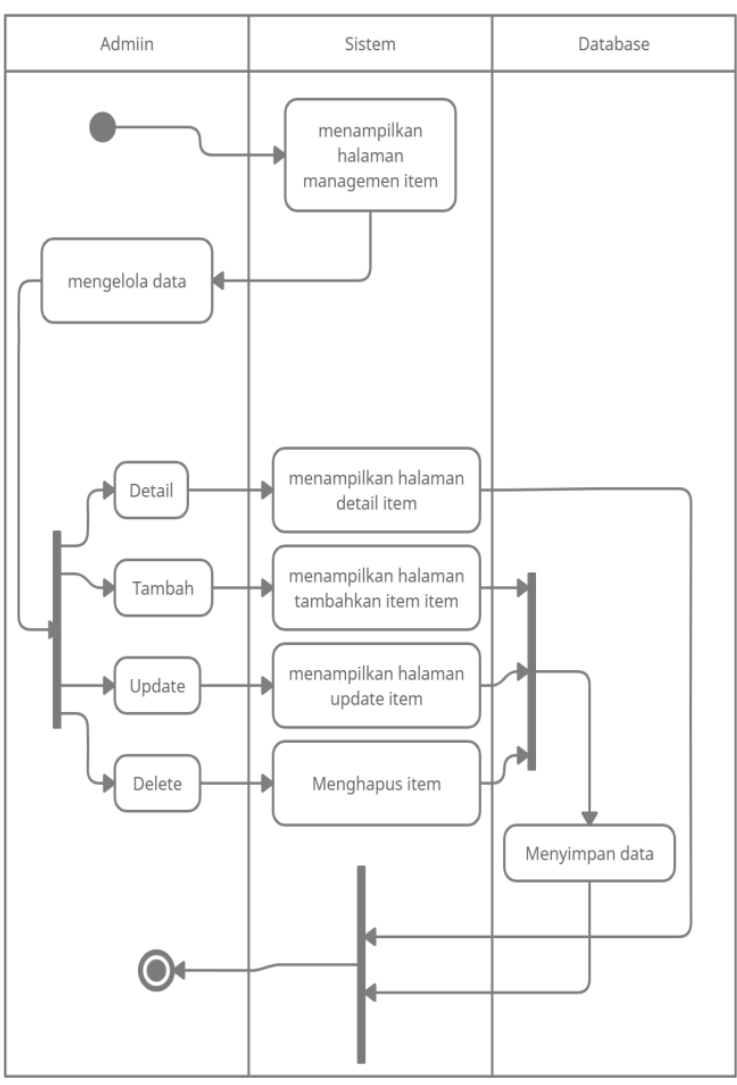

Gambar 6. Activity Diagram Managemen item

Gambar 6. Dalam mengelola data Item, Administrator akan mengakses halaman Management Item lalu sistem akan merespon dengan menampilkan data Item. Dimana Administrator mempunyai Hak untuk memanajemen data item.

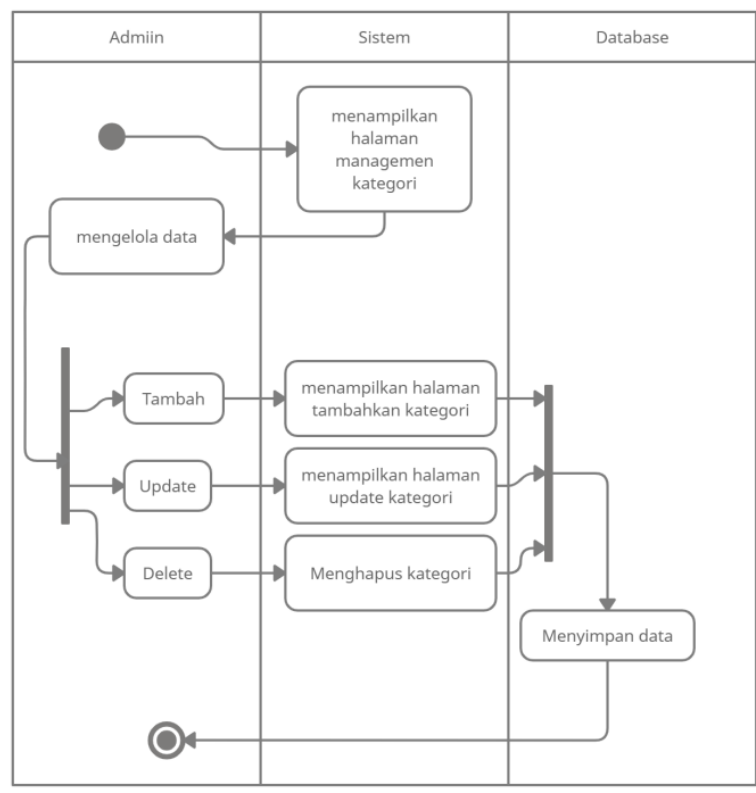

Gambar 7. Activity Diagram Manjemen Kategori 
Gambar 7. Dalam mengelola data Ketegori, Administrator akan mengakses halaman Management Kategori lalu sistem akan merespon dengan menampilkan data Item. Dimana Administrator mempunyai Hak untuk memanajemen data Kategori.

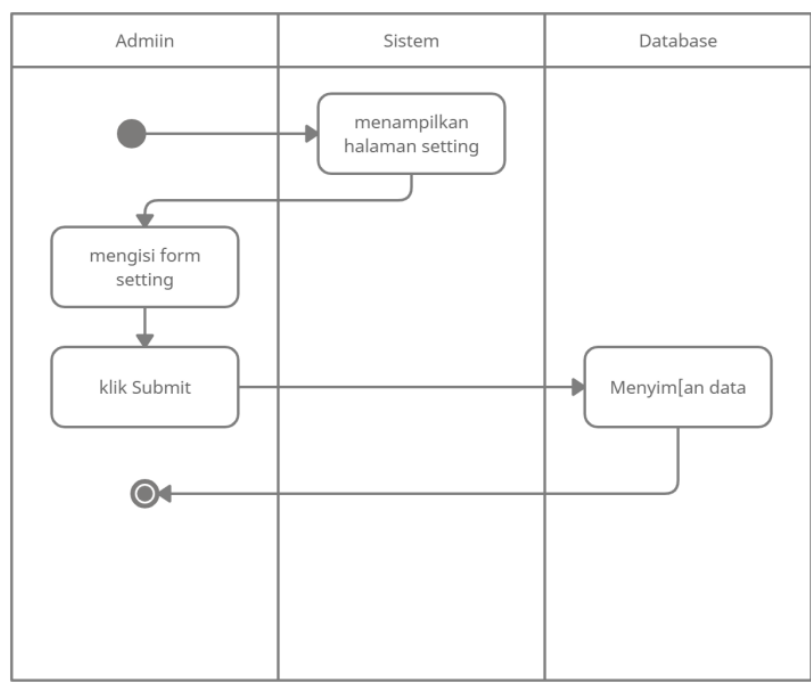

Gambar 8. Activity Diagram Setting

Gambar 8. Dalam mengelola data web, Administrator akan mengakses halaman Setting lalu sistem menampilkan data Setting. Dimana Administrator mempunyai Hak untuk mengubah data website seperti email, no tlp dan seagainya

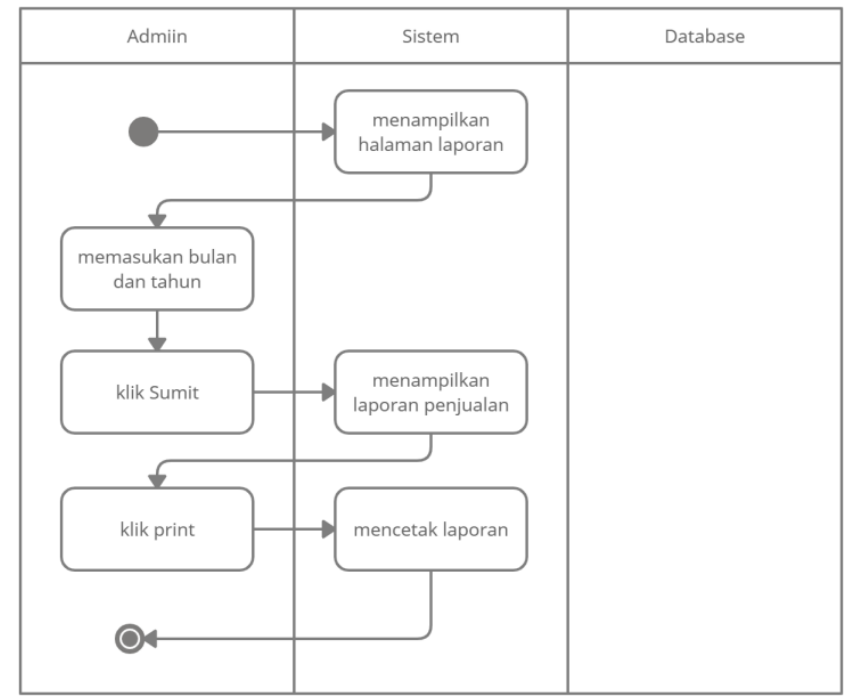

Gambar 9. Activity Diagram Laporan

Gambar 9. mengelola Laporan penjualan, Administrator akan mengakses halaman Laporan. Dimana Administrator dapat mengetahui laporan penjualan setiap bulan.

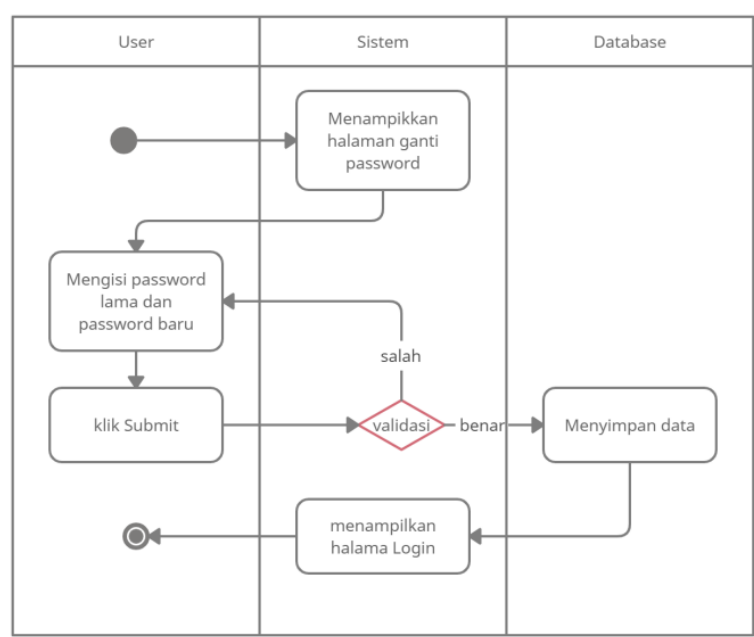

Gambar 10. Activity Diagram Ganti Password

Gambar 10. Dalam mengelola password, Administrator atau user akan mengakses halaman Ganti Password lalu sistem akan merespon dengan menampilkan form ganti password. Dimana Administrator dan User mempunyai hak untuk mengganti password akun miliknya.

\subsubsection{Entity Relationship Diagram (ERD)}

Entity Relationship Diagram (ERD) adalah penggambaran suatu rancangan basis data yang melibatkan hubungan atau relasi antar entitas atau object yang terlihat beserta atributnya, gambar 5 merupakan gambaran dari Entity Relationship Diagram penjualan ikan cupang di labetta solo.
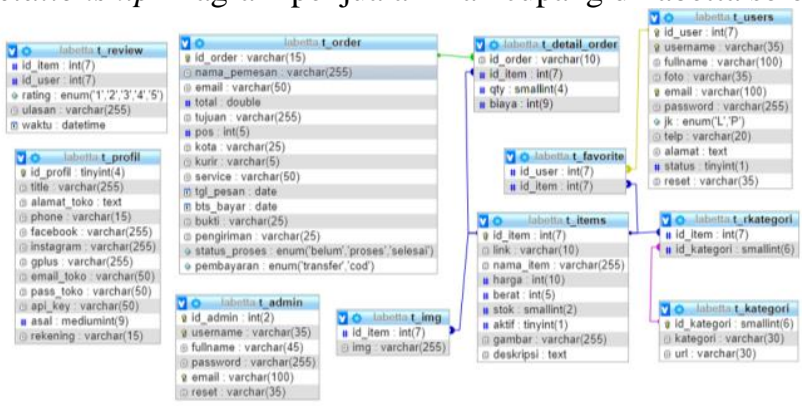

Gambar 11. Entity Relationship Diagram

\subsubsection{Design User Interface}

User Interface atau dikenal dengan UI adalah tampilan visual sebuah produk yang menjembatani sistem dengan pengguna (user). Tampilan UI dapat berupa bentuk, warna, dan tulisan yang didesain semenarik mungkin. Secara sederhana, UI adalah bagaimana tampilan sebuah produk dilihat oleh pengguna. Dalam proses pembuatan design user interface ini menggunakan tool MockFlow . Gambar dibawah merupakan desain User Interface dari sistem penjualan ikan cupang di Labetta Solo. 


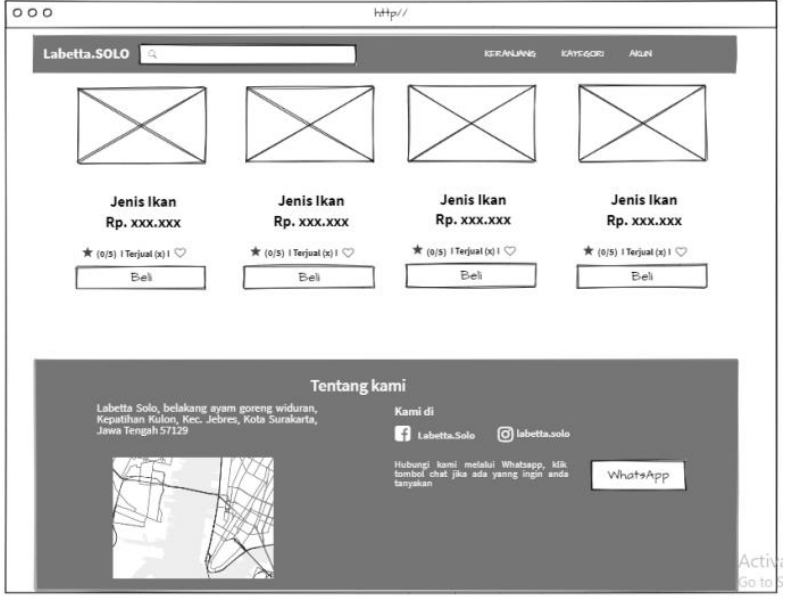

Gambar 12.Halaman Utama User

Gambar 12 adalah tampilan utama pada saat user masuk kedalam sisitem, tampilan ini berisikan daftar produk, maps atau alamat toko, serta terdapat tombol WhatsApp yang akan terhubung dengan whatsapp admin.

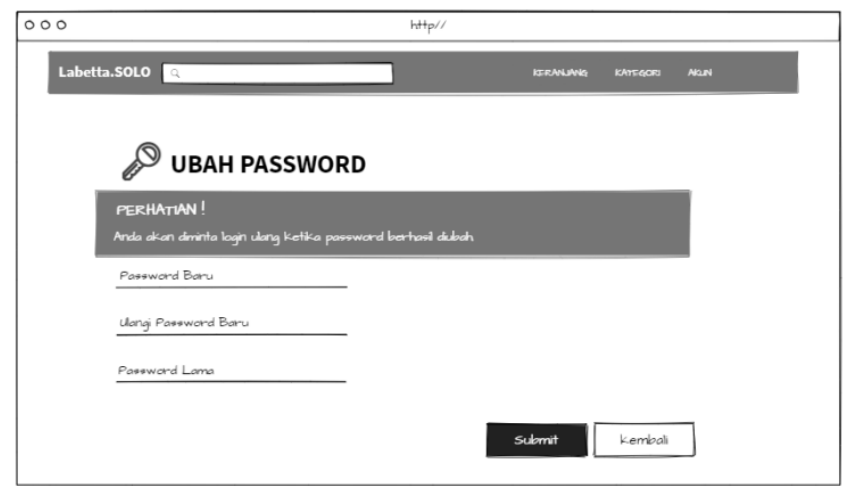

Gambar 13.Halaman Ubah Password

Gambar 13 Adalah tampilan saat user masuk ke dalam halaman ubah password, user harus menginputkan password baru dan password lama untuk merubah password.

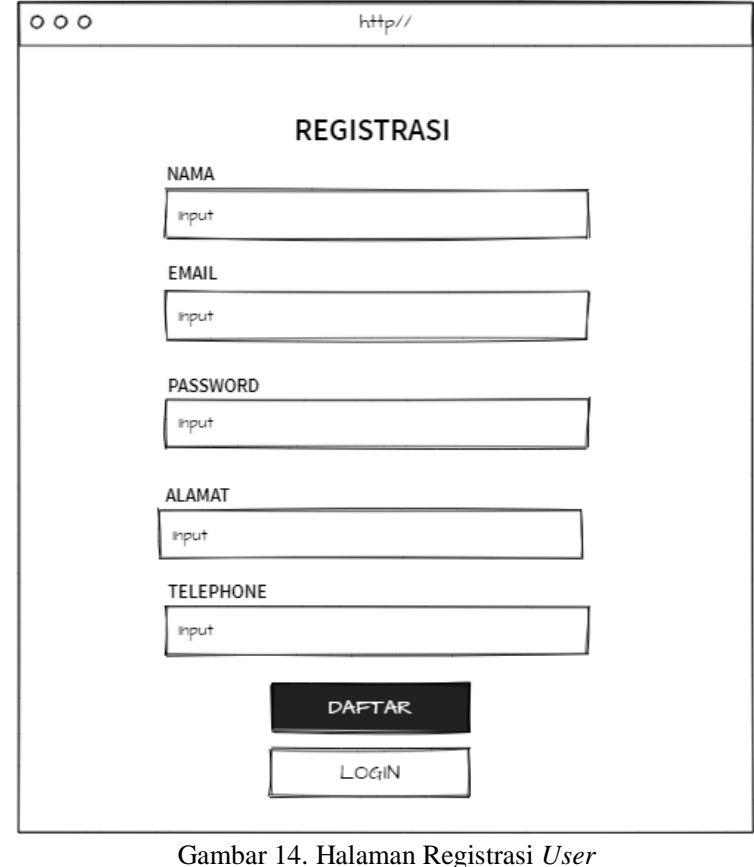

Gambar 14 merupakan halaman registrasi atau pendaftaran bagu user, user harus mngisikan form pendaftaran agar user terdaftar dan mendaptkan akses masuk ke sistem.

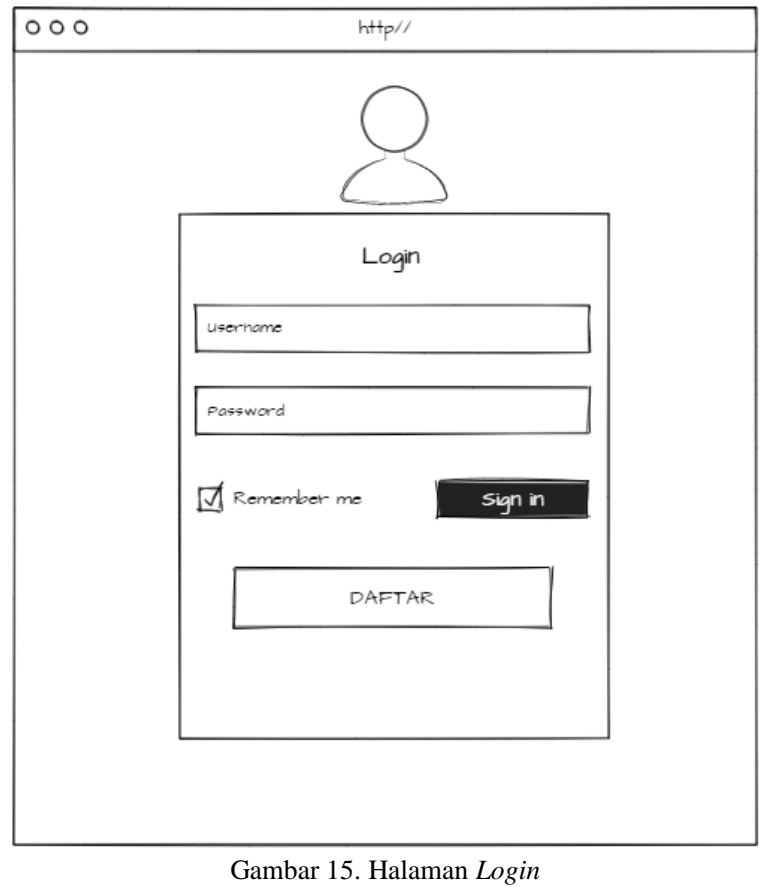

Gambar 15 adalah halaman login untuk masuk ke sistem dengan mengiskan username dan password yang terdaftar jika data yang dimasukkan sesuai maka sistem akan menamilkan halaman utama. 


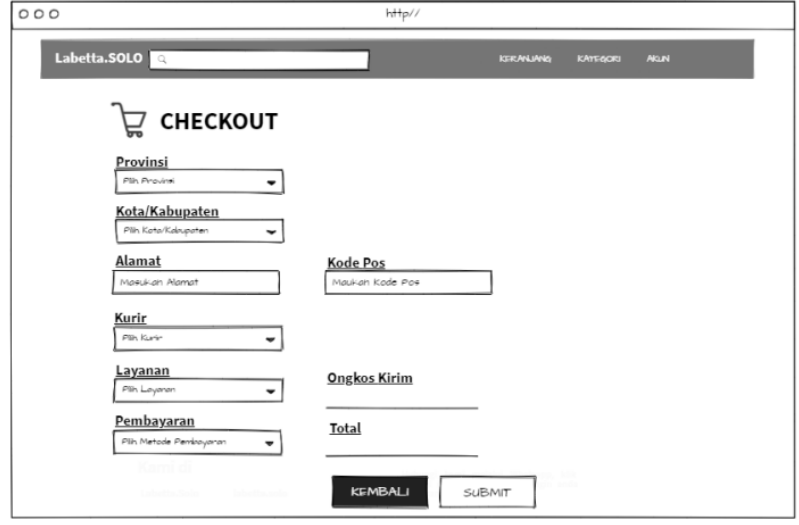

Gambar 16. Halaman Checkout User

Gambar 16 merupakan halaman checkout user untuk mengisi data alamat pengiriman, kurir dan total belanja yang harus dibayarkan oleh pembeli.

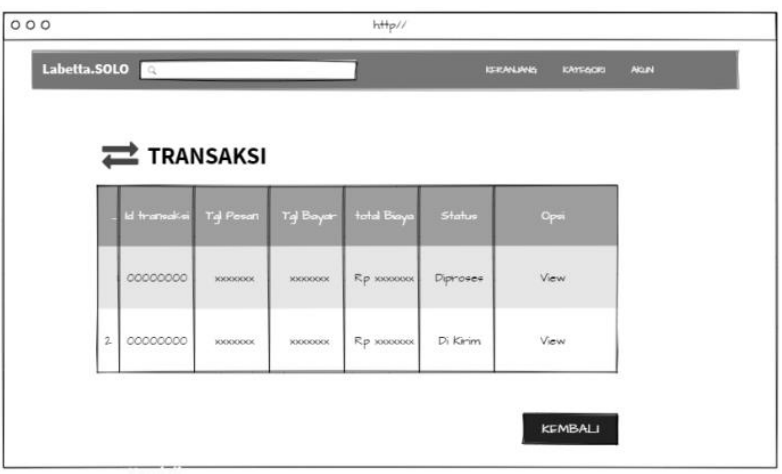

Gambar 17. Halaman Transaksi User

Gambar 17 halaman Transaksi user laman ini berupa daftar informasi transaksi yang dilakukan oleh user.

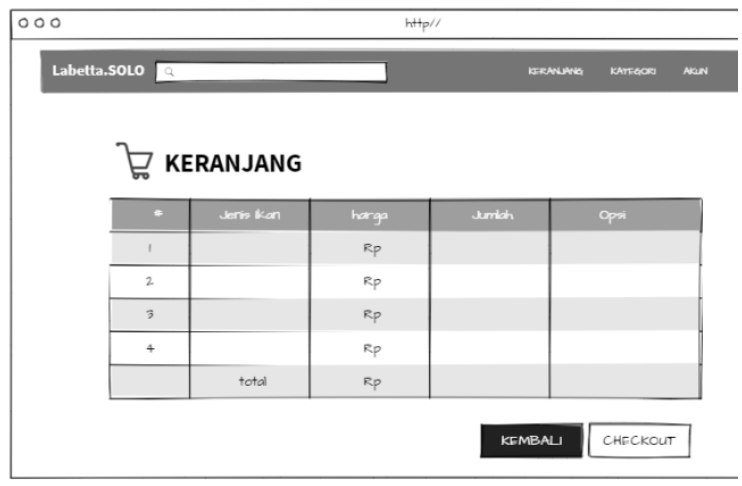

Gambar 18. Halaman Keranjang

Gambar 18 Halaman Keranjang user merupakan halaman daftar transaksi yang dilkukan oleh user.

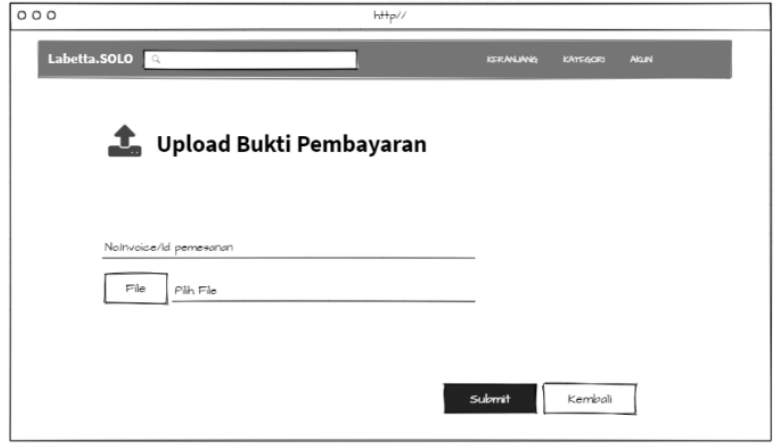

Gambar 19. Halaman Upload Bukti Bayar

Gambar 19 Halaman Upload Bukti Pembayaran merupakan halaman untuk mengupload struk bukti transfer dengan memasukkan No Invoice atau id pesanan dan upload foto struk bukti transfer.

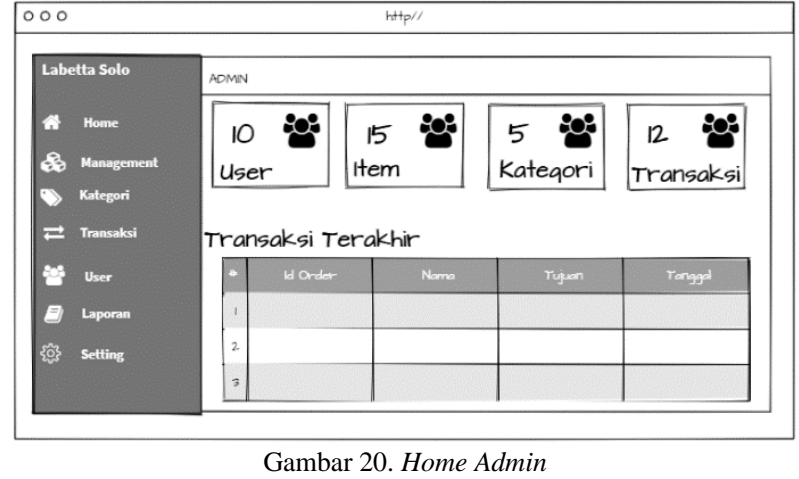

Gambar 20. tampilan Home Admin merupakan tampilan saat admin berhasil login, tampilan ini berisikan riwayat transaksi terkahir, jumlah user, item kategori dan transaksi berhasil.

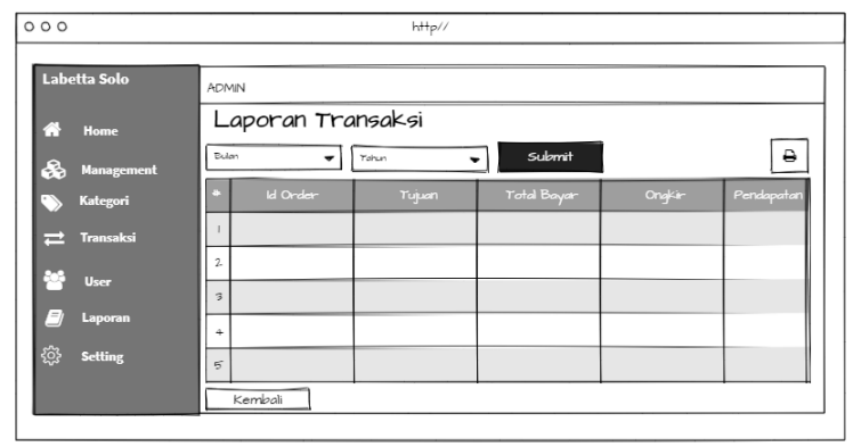

Gambar 21.Halaman Laporan

Gambar 21 Halaman Laporan merupakan halaman hasil laporan penghasilan dari transaksi penjualan ikan, laporan dapat dicetak bulanan. 


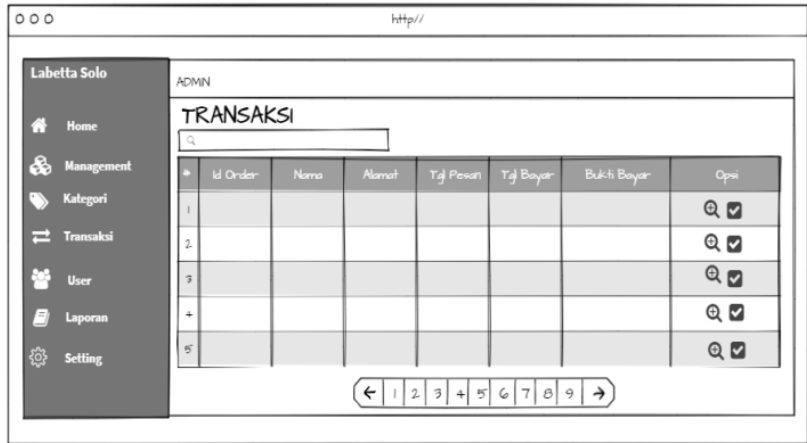

Gambar 22. Halaman Transaksi Admin

Gambar 22 halaman Transaksi admin berisikan informasi data pesanan dari user, admin dapat melihat detail transaksi dan mengkonfirmasi proses transaksi.

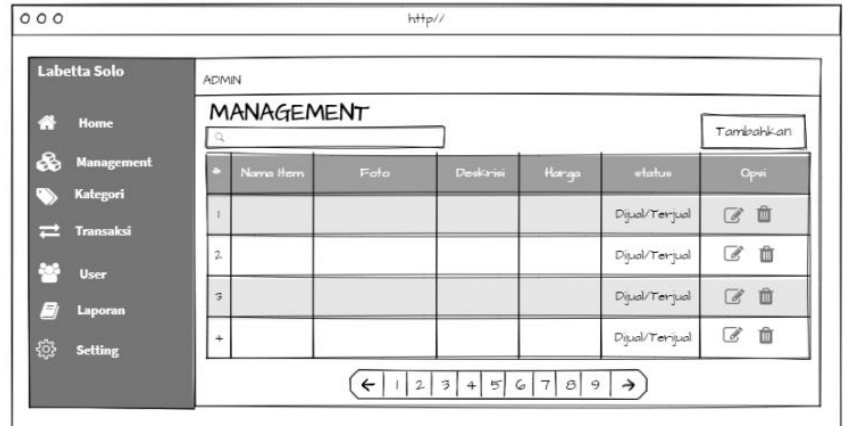

Gambar 23. Halaman Pengelolaan Data

Gambar 23 halaman pengelolaaan data, pada halaman ini admin dapat mengelola data ikan yang dijual seperti menambahkan, edit dan hapus data.

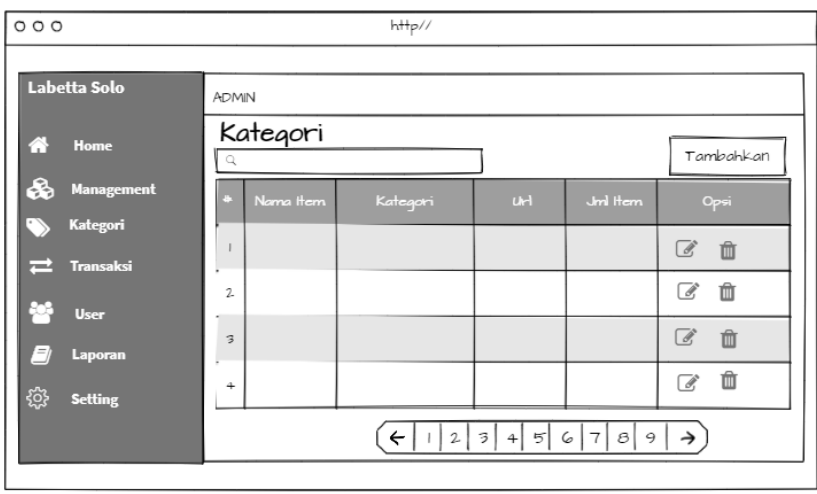

Gambar 24. Halaman Kategori

Gambar 24.Halaman Kategori merupakan halaman management data kategori admin, admin memiliki akses CRUD pada halaman kategori.

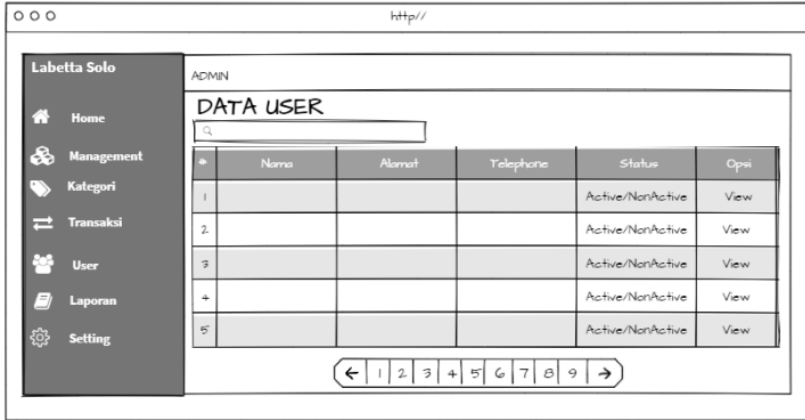

Gambar 25. Halaman Data User

Gambar 25 halaman data user yang berisikan seluruh informasi data mengenai user yang telah terdaftar.

\subsection{Coding}

Tahap ini merupakan tahap pembuatan aplikasi dengan menggunakan php sebagai bahas pemrograman dan penggunaan tool Framework CodeIgniter 3(PHP), Sublime Text Editor, XAMPP, database MySQL,

Arsitektur yang digunakan pada Codeigniter dibagi menjadi 3 komponen yaitu MVC (Model, View, Controller). Sehingga setiap komponen memiliki file codingan masingmasing yang saling terhubung.

- Model, Bertugas untuk mengatur, menyiapkan, memanipulasi dan mengorganisasikan data (dari database) sesuai dengan instruksi dari controller. Sehingga terdapat codingan :

$>$ Admin.php menerima respons dari controller yang terkait dengan tabel Admin atau lebih dari satu tabel tetapi memiliki fungsi yang sama dalam mengelola data admin.

> Items.php menerima respons dari controller yang terkait dengan tabel Items atau lebih dari satu tabel tetapi memiliki fungsi yang sama dalam mengelola data item.

$>$ Trans.php menerima respons dari controller yang terkait dengan tabel order atau lebih dari satu tabel tetapi memiliki fungsi yang sama dalam mengelola data transaksi.

> Users.php menerima respon dari controller yang berhubungan dengan tabel User ataupun lebih dari satu tabel tetapi memiliki function yang sama dalam mengelola data User.

- View, Bertugas untuk menyajikan informasi (yang mudah dimengerti) kepada user sesuai dengan instruksi dari controller. Terdapat 2 Views yaitu untuk Administrator dan Customer.

- Administrator

$>$ Home.php menampilkan halaman home admin.

$>$ Laporan.php menampilkan laporan penjualan.

$>$ Manage_item.php menmpilkan halaman untuk mengelola data item.

$>$ Tag.php menampilkna halaman untuk mengelola data kategori. 
$>$ Transaksi.php menampilkan halaman transaksi admin.

$>$ Manage_user.php menampilkna halaman data user.

- Customer

$>$ Pass.php menampilkan halaman ubah password.

$>$ Checkout.php menampilkan form pengisisan alamat dan metode pembayaran.

$>$ Login.php menampilkan halaman login.

$>$ Register.php menampilkna halama registrasi.

$>$ Up_bukti.php menampilkan halaman untuk mengupload bukti sudah dilakukannya pembayaran.

$>$ Review_data.php menampilkna halaman review data barang.

$>$ User_profil.php menampilkan halaman data user.

- Controller, Bertugas untuk mengatur apa yang harus dilakukan model, dan view mana yang harus ditampilkan berdasarkan permintaan dari user. Namun, terkadang permintaan dari user tidak selalu memerlukan aksi dari model.

$>$ Checkout.php merespon request dari user yang berhubungan dengan checkout.

> Item.php merespon request dari user dalam mengelola data item entah untuk menampilkan detail data item atau CRUD terhadap data item.

$>$ Login.php merespon request dari user yang berhubungan dengan Login dan Logout sistem.

$>\quad$ Setting.php merespon request dari user yang berhubungan dengan setting dalam mengelola website admin entah untuk menampilkan data atau CRUD terhadap data pada website admin.

$>$ Transaksi.php merespon request dari user yang berhubungan dengan user dalam mengelola user entah untuk menampilkan detail data user atau CRUD terhadap data user.

> User.php merespon request dari user yang berhubungan dengan user dalam mengelola user entah untuk menampilkan detail data user atau CRUD terhadap data user.

Selain itu terdapat software third-parties yang digunakan untuk mengembangkan program serta mendukung proses yang dilakukan oleh user. Sistem dikembangkan mengacu pada kemampuan Administrator dan Customer dalam mengaplikasikannya. Langkah ini diambil guna mempermudah Administrator dan Pembeli dalam penggunaan sistem pada saat di implementasikan.

\subsection{Testing}

Dari hasi code yang sudah jadi selanjutnya memasuki tahap testing atau pengujian yang bertujuan untuk sejauh mana sistem yang dibuat dapat berjalan, tahap testing ini akan menggunakan metode kuesioner dan black box, Pengujian kuisioner dilakukan dengan System Usability Scale (SUS). Uji black box merupakan salah satu standar pengujian sistem untuk menilai fungsionalitasnya, apakah fungsionalitas sistem sudah sesuai antara perencanaan dan setelah dikembangkan. Pengujian black box digunakan pada penelitian ini karena proses yang tidak terlalu kompleks untuk sistem informasi dengan skala kecil. Sementara itu, setiap program yang dibuat tentu memerlukan tahapan pengujian kepada user untuk menilai apakah aplikasi sudah sesuai dan user merasa aplikasi tersebut memiliki kebergunaan. Penelitian ini menggunakan metode pengujian System Usability Scale untuk mendapatkan perspektif pengguna agar hasil akhir yang didapat sesuai dengan kebutuhan, dengan kata lain apabila pengguna menyatakan fungsi telah sesuai dengan apa yang dipahami oleh pengguna, maka fitur aplikasi telah berfungsi dengan baik. black box digunakan untuk memastikan spesifikasi dan sistem tidak mengalami kesalahan atau eror pada output dari input yang diberikan. Pengujian sistem akan dilakukan menggunakan perangkat $\mathrm{PC}$ atau Laptop yang sudah terinstall $X A M P P$ sebagai local server. Dalam tahap ini belum dilakukan hosting karena masih dalam tahap pengujian. Hasil pengujian dijadikan sebagai acuan dalam perbaikan sebelum sistem diimplementasikan.

\subsection{Implementasi}

Pada tahap terakhir ini sistem yang telah dibuat dan telah di uji maka sistem akan di gunakan kan oleh pemilik labetta solo, sistem yang sudah sempurna dapat di hosting dengan menyewa jasa hosting berbayar seperti Hostinger Indonesia, Niagahoster, SiteGround agar keamanan sistem dapat terjaga lebih baik, selain itu sistem ini akan mendapatkan pemeliharaan seperti memperbaiki kesalahan sistem yang ditemukan oleh user. sistem akan dijalankan pada perangkat keras PC (Personal Computer) atau menggunakan laptop melalui browser diantaranya Google Chrome, Opera, Mozilla Firefox atau browser lain yang tersedia.

\section{HASIL DAN PEMBAHASAN}

Penelitian ini menghasilkan sistem informas penjualan ikan cupang berbasis web pada Labetta Solo sistem yang dihasilkan memiliki interface sesuai yang diharapkan, sistem ini juga dapat melaporkan hasil penjualan secara otomatis dan juga pemasaran ikan di labetta solo.

\subsection{Hasil Penelitian}




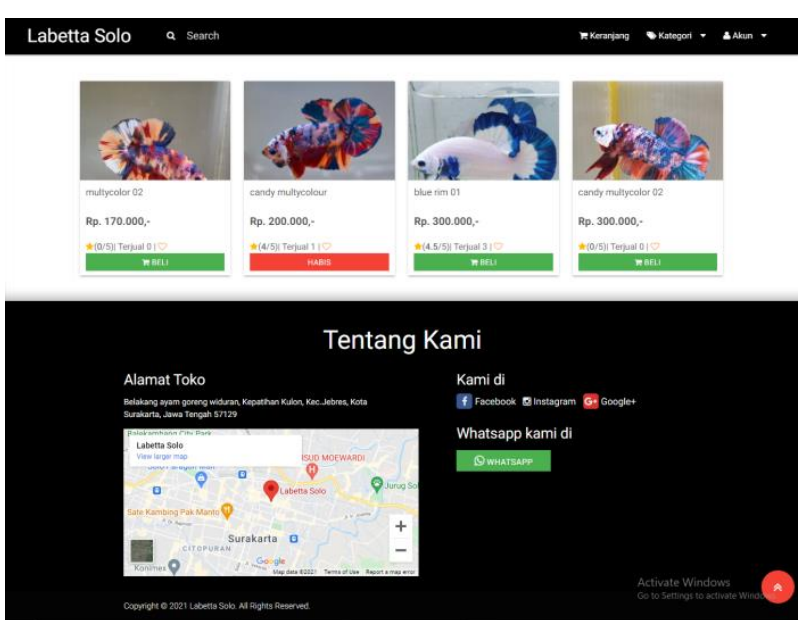

Gambar 26. Home User

Gambar 26 Tampilan halaman utama dari user, disini user dapat memilih ikan dan membeli ikan dengan mengklik tombol beli jika stok masih ada maka istem akan ditambahkan ke keranjang, untuk melihat detail item user bisa mengklik gambar maka akan masuk ke halaman detail item. Terdapat rating penjualan, jumlah terjual dan favorite untuk menambahkan favorit ke dalam daftar favorite user.

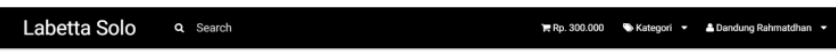

F Data Belanja

Gambar 27. Keranjang

Gambar 27 merukapan halaman keranjang yang menambpilkan daftar data belanja user di halaman ini user dapat meghapus atau mengubah data belanja.

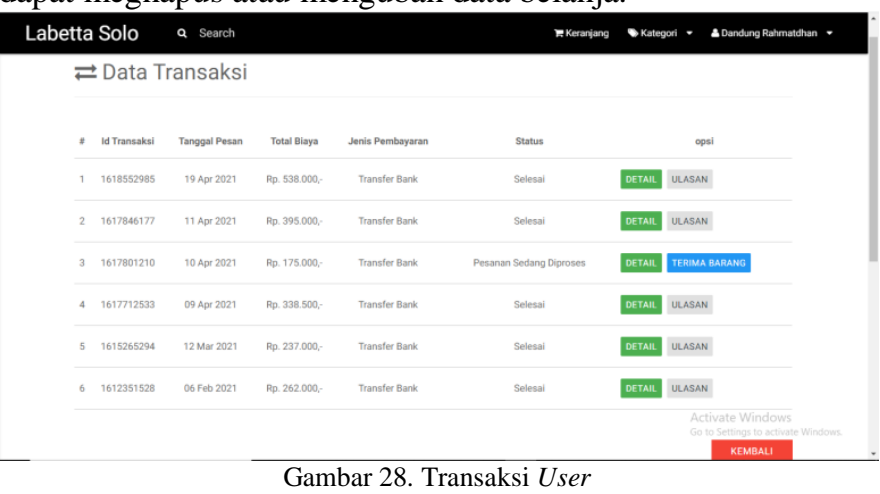

Gambar 28 Halaman Transaksi user berisikan daftar teransaki yang dilakua oleh user, terdapat satatus untuk melihat proses dari transaksi pembelian dan beberapa opsi sepert detail untuk melihat detail pembelian dan bukti pengiriman, Terima barang untuk mengkonfirmasi ke admin bahwa barang sudah diterima, dan Ulasan untuk berikan penilaian produk yang dibeli.

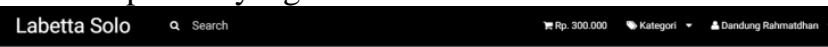

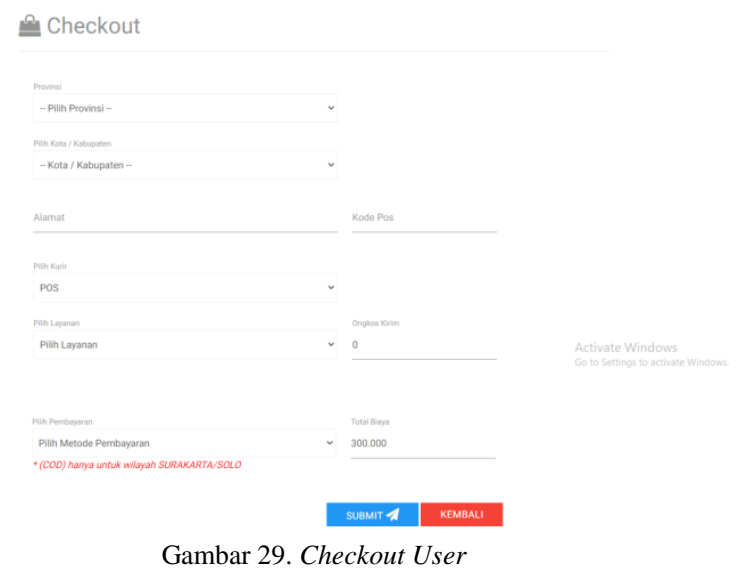

Gambar 29. Halaman checkout user berisikan data alamat pengirman dan opsi kurir pengiriman unutk menghitung ongkos kirim, secara otomatis ongkos kirim akan ditambahka dengan harga barang yang dibeli, untuk metode pembayaran user bisa memilih COD (Cash On Delivery) untuk costumer ayng berada di wilayah Surakarta dan Transfer untuk luar kota Surakarta.

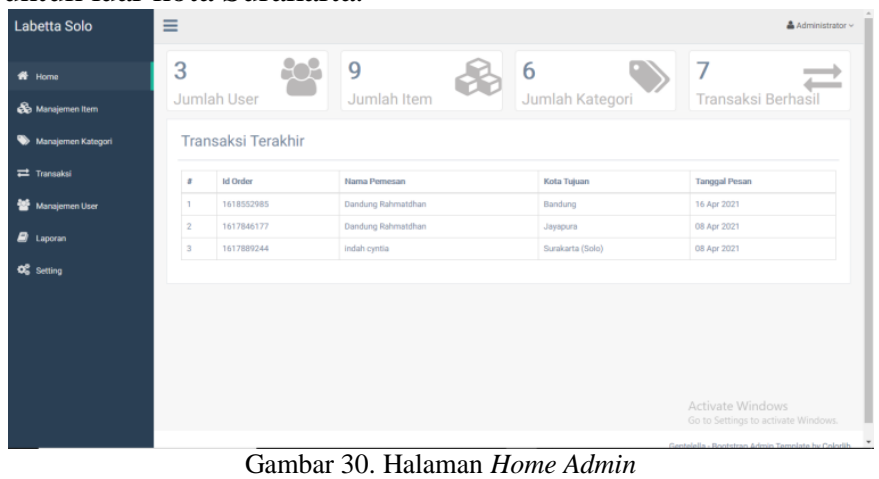

Gambar 30. Halaman Home admin berisikan daftar teransaksi terakhir,jumlah user, jumlah item, jumlah kategori, dan jumlah transaksi berhasil

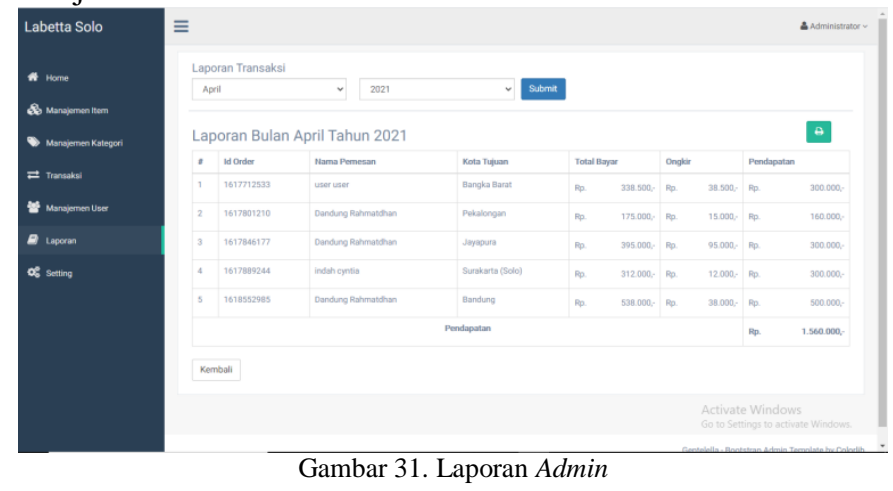

Gambar 31. Halaman Laporan admin melaporkan hasil penjualan selama periode bulan maka akan muncul pendapatan jumlah penjuala ikan selama periode satu bulan, 
admin dapat mencetak laporan untuk bukti fisik hasil laporan penjualan.

\subsection{Pengujian Black Box}

Pengujian adalah suatu rangkaian aktifitas yang terencana dan sistematis untuk menguji atau mengevaluasi kebenaran yang diinginkan [15]. pengujan Black Box merupakan metode untuk menguji sistem yang telah dibuat, untuk menentukan bug atau gangguan pada sistem sebelum sistem di implementasikani, tanpa harus memperhatikan detail software [16]. Adanya software testing kita tidak dapat mengetahui apakah sistem tersbut sudah memenuhi semua kriteria yang dibutuhka oleh user. Pengujian black box berfokus pada input yang tersedia dan output yang diharapkan tanpa pengetahuan tentang internal programnya. Hasil pengujian black box pada sistem penjualan ikan cupang berbasis web di Labetta Solo dapat dilihat pada Tabel 1 berikut.

TABle I. Pengujian Black Box

\begin{tabular}{|c|c|c|c|c|}
\hline No & Pengujian & $\begin{array}{c}\text { Kondisi } \\
\text { Pengujian }\end{array}$ & Harapan & Hasil \\
\hline 1 & Login & $\begin{array}{l}\text { Username dan } \\
\text { Password salah } \\
\text { Username dan } \\
\text { password benar }\end{array}$ & $\begin{array}{l}\text { Kembali ke } \\
\text { halaman login } \\
\text { Sistem masuk } \\
\text { ke halaman } \\
\text { utama }\end{array}$ & Berhasil \\
\hline 2 & Logout & $\begin{array}{l}\text { Keluar dari sistem } \\
\text { dan menampilkan } \\
\text { halaman login }\end{array}$ & $\begin{array}{l}\text { Sistem berhasil } \\
\text { keluar dan } \\
\text { menampilkan } \\
\text { halaman login }\end{array}$ & Berhasil \\
\hline 3 & Registrasi & $\begin{array}{l}\text { Mengakses form } \\
\text { registrasi, } \\
\text { menginputkan } \\
\text { nama depan, nama } \\
\text { belakang, email, } \\
\text { dan password. }\end{array}$ & $\begin{array}{l}\text { Email verifikasi } \\
\text { terkirim ke } \\
\text { email user dan } \\
\text { mengarah ke } \\
\text { halaman login. }\end{array}$ & Berhasil \\
\hline 4 & $\begin{array}{l}\text { Ganti } \\
\text { password }\end{array}$ & $\begin{array}{l}\text { Akses halaman } \\
\text { ganti password, } \\
\text { masukan } \\
\text { password baru, } \\
\text { masukan } \\
\text { password baru } \\
\text { sekali lagi, } \\
\text { masukan } \\
\text { password lama, } \\
\text { klik submit }\end{array}$ & $\begin{array}{l}\text { Kembali ke } \\
\text { halaman login } \\
\text { untuk login } \\
\text { menggunakan } \\
\text { password baru }\end{array}$ & Berhasil \\
\hline 5 & $\begin{array}{l}\text { Menambahka } \\
\mathrm{n} \text { produk ke } \\
\text { Keranjang }\end{array}$ & $\begin{array}{l}\text { Mengakses } \\
\text { halaman detail } \\
\text { produk atau quick } \\
\text { view, klik tombol } \\
\text { Beli }\end{array}$ & $\begin{array}{l}\text { Muncul modal } \\
\text { yang berisi } \\
\text { daftar produk } \\
\text { yang ada di } \\
\text { Cart. }\end{array}$ & Berhasil \\
\hline 6 & $\begin{array}{l}\text { Menghapus } \\
\text { produk dari } \\
\text { Keranjang }\end{array}$ & $\begin{array}{l}\text { Klik halaman } \\
\text { keranjang, lalu } \\
\text { klik icon 'Trash'. }\end{array}$ & $\begin{array}{l}\text { Produk hilang } \\
\text { dari Keranjang. }\end{array}$ & Berhasil \\
\hline 7 & $\begin{array}{l}\text { Pemesanan } \\
\text { produk }\end{array}$ & $\begin{array}{l}\text { Akses halaman } \\
\text { Keranjang, lalu } \\
\text { klik Checkout } \\
\text { akan mengarah ke } \\
\text { halaman }\end{array}$ & $\begin{array}{l}\text { Muncul } \\
\text { notifikasi } \\
\text { pemesanan } \\
\text { berhasil } \\
\text { dilakukan dan }\end{array}$ & Berhasil \\
\hline
\end{tabular}

\begin{tabular}{|c|c|c|c|c|}
\hline & & $\begin{array}{l}\text { Checkout, mengisi } \\
\text { form yang } \\
\text { berkaitan dengan } \\
\text { informasi data diri } \\
\text { dan pengiriman. } \\
\text { Klik Submit. }\end{array}$ & $\begin{array}{l}\text { email } \\
\text { pemberitahuan } \\
\text { informasi } \\
\text { mengenai order } \\
\text { terkirim ke } \\
\text { email user. }\end{array}$ & \\
\hline 8 & $\begin{array}{l}\text { Upload Bukti } \\
\text { pembayaran }\end{array}$ & $\begin{array}{l}\text { Mengakses } \\
\text { halaman Bukti } \\
\text { Pembayaran, lalu } \\
\text { mengisi form no } \\
\text { invoice atau id } \\
\text { pesanan dan } \\
\text { upload file } \\
\text { gambar bukti } \\
\text { transfer lalu klik } \\
\text { tombol submit. }\end{array}$ & $\begin{array}{l}\text { Muncul alert } \\
\text { bahwa } \\
\text { pengiriman } \\
\text { berhasil }\end{array}$ & Berhasil \\
\hline 9 & Ulasan & $\begin{array}{l}\text { Mengakses } \\
\text { halaman ulasan } \\
\text { pada transaksi } \\
\text { yang berhasil lalu } \\
\text { mengisi atau edit } \\
\text { bintang dan form } \\
\text { keterangan. }\end{array}$ & $\begin{array}{l}\text { Sistem berhasil } \\
\text { menambahkan } \\
\text { atau mengedit } \\
\text { ulasan }\end{array}$ & Berhasil \\
\hline 10 & $\begin{array}{l}\text { Menambahka } \\
\text { n Favorit }\end{array}$ & $\begin{array}{l}\text { Klik icon love } \\
\text { pada halaman } \\
\text { utama atau pada } \\
\text { detail produk. }\end{array}$ & $\begin{array}{l}\text { Item berhasil } \\
\text { ditambahkan ke } \\
\text { favorit }\end{array}$ & Berhasil \\
\hline 11 & $\begin{array}{l}\text { Menghapus } \\
\text { Favorite }\end{array}$ & $\begin{array}{l}\text { Klik icon love } \\
\text { pada halaman } \\
\text { utama atau pada } \\
\text { detail produk. }\end{array}$ & $\begin{array}{l}\text { Item berhasil } \\
\text { dihapus dari } \\
\text { favorit }\end{array}$ & Berhasil \\
\hline 12 & Favorite & $\begin{array}{l}\text { Sistem menampil } \\
\text { view data favorite }\end{array}$ & $\begin{array}{l}\text { Sistem dapat } \\
\text { menampilkan } \\
\text { view data } \\
\text { favorite }\end{array}$ & Berhasil \\
\hline 13 & $\begin{array}{l}\text { Halaman } \\
\text { profil user }\end{array}$ & $\begin{array}{l}\text { Menampilkan } \\
\text { view data user dan } \\
\text { melakukan edit } \\
\text { data } \text { user. }\end{array}$ & $\begin{array}{l}\text { Sistem dapat } \\
\text { menampilkan } \\
\text { view data } \text { user } \\
\text { dan melakukan } \\
\text { edit data } \text { user }\end{array}$ & Berhasil \\
\hline 14 & $\begin{array}{l}\text { Mengelola } \\
\text { item }\end{array}$ & $\begin{array}{l}\text { Menampilkan } \\
\text { view data item } \\
\text { dan melakukan } \\
\text { CRUD pada data } \\
\text { item }\end{array}$ & $\begin{array}{l}\text { Sistem dapat } \\
\text { menampilkan } \\
\text { view data item } \\
\text { dan melakukan } \\
\text { CRUD pada } \\
\text { data item } \\
\end{array}$ & Berhasil \\
\hline 15 & $\begin{array}{l}\text { Mengelola } \\
\text { kategori }\end{array}$ & $\begin{array}{l}\text { Menampilkan } \\
\text { view data kategori } \\
\text { dan melakukan } \\
\text { CRUD pada data } \\
\text { kategori }\end{array}$ & $\begin{array}{l}\text { Sistem dapat } \\
\text { menampilkan } \\
\text { view data } \\
\text { kategori dan } \\
\text { melakukan } \\
\text { CRUD pada } \\
\text { data kategori }\end{array}$ & Berhasil \\
\hline 16 & Setting & $\begin{array}{l}\text { Menampilkan } \\
\text { view data setting } \\
\text { dan melakukan } \\
\text { edit pada data } \\
\text { setting }\end{array}$ & $\begin{array}{l}\text { Sistem dapat } \\
\text { menampilkan } \\
\text { view data } \\
\text { setting dan } \\
\text { melakukan edit } \\
\text { pada data } \\
\text { setting }\end{array}$ & Berhasil \\
\hline 17 & $\begin{array}{l}\text { Manajemen } \\
\text { user }\end{array}$ & $\begin{array}{l}\text { Menampilkan } \\
\text { view data user dan } \\
\text { mengubah status } \\
\text { user }\end{array}$ & $\begin{array}{l}\text { Sistem dapat } \\
\text { menampilkan } \\
\text { view data user } \\
\text { dan mengubah } \\
\text { status } \text { user. }\end{array}$ & Berhasil \\
\hline
\end{tabular}




\begin{tabular}{|c|l|l|l|l|}
\hline \multirow{2}{*}{18} & $\begin{array}{l}\text { Menampilkan } \\
\text { Halaman } \\
\text { Laporan }\end{array}$ & $\begin{array}{l}\text { Sistem data laporan } \\
\text { menampilkan } \\
\text { sesuai periode } \\
\text { yang diinginkan } \\
\text { dan mencetak } \\
\text { laporan sesuai } \\
\text { laporan penjualan }\end{array}$ & $\begin{array}{l}\text { periode yang } \\
\text { diinginkan dan } \\
\text { mencetak } \\
\text { laporan } \\
\text { penjualan }\end{array}$ & Berhasil \\
\hline 19 & $\begin{array}{l}\text { Konfirmasi } \\
\text { pembayaran }\end{array}$ & $\begin{array}{l}\text { Menampilkan } \\
\text { halaman transaksi } \\
\text { view data } \\
\text { transaksi jika } \\
\text { benar klik } \text { icon } \\
\text { "centang" }\end{array}$ & $\begin{array}{l}\text { Sistem } \\
\text { mengubah } \\
\text { status } \\
\text { pembayaran } \\
\text { pada user }\end{array}$ & Berhasil \\
\hline
\end{tabular}

\subsection{Pengujian System Usability Scale (SUS)}

Usability testing umumnya diringkas sebagai kualitas kenyamanan sistem. Kegunaan meliputi efektifitas, efisiensi, dan kepuasan pengguna terhadap sistem [17]. SUS (System Usability Scale) merupakan kuesioner yang dapat digunakan untuk mengukur usability sistem komputer menurut sudut pandang subyektif pengguna, metode System Usability Scale ini dilakukan dengan menyebarkan kuesioner kepada responden. Pengujian ini bertujuan untuk mengetahui penilaian pengguna terhadap sistem yang berhasil dikembangkan [18]. Tes SUS memiliki 10 jenis pertanyaan seperti pada Tabel 2 dan terdapat 5 pilihan jawaban yang telah ditentukan antara lain "Sangat Tidak Setuju", "Tidak Setuju", "Ragu-ragu", "Setuju", dan "Sangat Setuju", setiap jawaban memiliki skor 1-5. Untuk pertanyaan bernomor ganjil, skor dihitung dengan cara skor pertanyaan dari pengguna dikurangi 1 . Sedangkan untuk pertanyaan bernomor genap skor akhir didapat dari nilai 5 dikurangi skor pertanyaan yang didapat dari pengguna.

\section{TABLE 2. PERTANYAAN SUS}

\begin{tabular}{|c|l|}
\hline No & \multicolumn{1}{|c|}{ Pertanyaan (P) } \\
\hline 1 & Saya berpikir akan menggunakan sistem ini lagi. \\
\hline 2 & Saya merasa sistem ini rumit untuk digunakan. \\
\hline 3 & Saya merasa sistem ini mudah digunakan. \\
\hline 4 & $\begin{array}{l}\text { Saya membutuhkan bantuan dari orang lain atau teknisi dalam } \\
\text { menggunakan sistem ini }\end{array}$ \\
\hline 5 & Saya merasa fitur-fitur sistem ini berjalan dengan semestinya. \\
\hline 6 & $\begin{array}{l}\text { Saya merasa ada banyak hal yang tidak konsisten (tidak serasi } \\
\text { pada sistem ini). }\end{array}$ \\
\hline 7 & $\begin{array}{l}\text { Saya merasa orang lain akan memahami cara menggunakan sistem } \\
\text { ini dengan cepat. }\end{array}$ \\
\hline 8 & Saya merasa sistem ini membingungkan. \\
\hline 9 & Saya merasa tidak ada hambatan dalam menggunakan sistem ini. \\
\hline 10 & $\begin{array}{l}\text { Saya perlu membiasakan diri terlebih dahulu sebelum } \\
\text { menggunakan sistem ini. }\end{array}$ \\
\hline
\end{tabular}

Penilaian dari responden berhasil dikumpulkan maka selanjutnya dilakukan perhitungan terhadap nilai tersebut guna mendapatkan skor SUS. Gambar 32 memperlihatkan kategori penerimaan skor SUS. Skor akan dianalisa dan diinterpretasikan menggunakan kategori penerimaan (Acceptability), skala nilai (Grade), dan Adjectives Ratings. minimal skor SUS atau rata-rata yang harus diperoleh sistem agar dapat dikategorikan sebagai sistem yang layak adalah sebesar 70 [19].

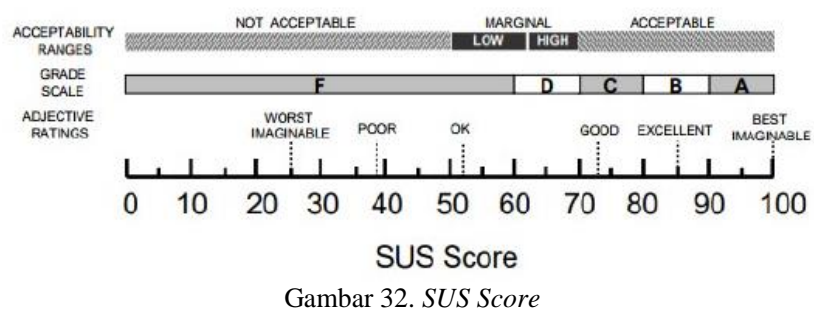

TABLE 3. PEHITUNGAN SKOR SUS RESPONDEN

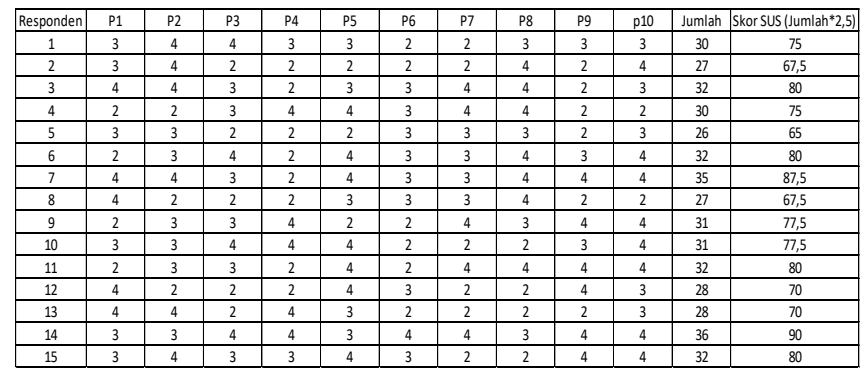

Tabel 3 merupakan hasil perhitungan skor SUS dari masing-masing responden. Skor SUS responden secara keseluruhan diperoleh nilai rata-rata 75,83 dari total 15 responden. Dengan demikian dapat dikatakan bahwa media tergolong Acceptable dengan kisaran rata-rata 71-100 [20], dari skor tersebut mendapatkan nilai grade scale $\mathrm{C}$ dengan adjective rating Good dan masuk dalam kategori penerimaan Acceptable.

\section{KesIMPULAN}

Penelitian ini membahas mengenai pengembangan sistem informasi penjualan ikan di toko ikan hias Labetta solo. Sistem yang dikembangkan mengikuti metode pengembangan perangkat lunak waterfall. Sistem informasi penjualan dikembangakan menggunakan php framework dengan data base mysql. Hasil pengujian sistem melalui uji black box dan SUS menunjukkan bahwa secara fungsionalitas sistem berjalan sangat baik terbukti dari tidak ditemukannya error pada sistem. Selanjutnya pengujian dengan SUS yang melibatkan user untuk memberikan penilaian terhadap sistem menunjukkan nilai rata-rata 75,83 yang berarti sistem informasi yang dikembangkan memiliki level Acceptable dan bisa diterima oleh user untuk digunaka.

\section{REFERENCES}

[1] A. Mukti, M. Arief, L. Sari, N. Dewi, and A. Rahayu, "PERBEDAAN METODE PEMELIHARAAN IKAN HIAS PADA KELOMPOK PEMBUDIDAYA IKAN HIAS DI DESA KARANG SENTUL, KECAMATAN GONDANG WETAN, KABUPATEN PASURUAN, PROPINSI JAWA TIMUR," Angew. Chemie Int. Ed. 6(11), 951-952., vol. 10, no. 1, pp. 11-17, 2019.

[2] L. T. T. Tran, "Managing the effectiveness of e-commerce platforms in a pandemic," J. Retail. Consum. Serv., vol. 58, no. August 2020, p. 102287, 2021, doi: 10.1016/j.jretconser.2020.102287.

[3] H. Hwangbo, Y. S. Kim, and K. J. Cha, "Recommendation system development for fashion retail e-commerce," Electron. Commer. Res. Appl., vol. 28, pp. 94-101, 2018, doi: 10.1016/j.elerap.2018.01.012. 
[4] F. E. Khoironi and I. A. N. Saskara, "Analisis Pengaruh Kurs Dollar, Inflasi, dan Produksi terhadap Ekspor Ikan Hias di Provinsi Bali," EJournal EP Unud, vol. 6, no. 3, pp. 337-361, 2015.

[5] R. Destriana, "Analisis Dan Perancangan E-Bisnis Dalam Budidaya Dan Penjualan Ikan Cupang Menggunakan Metodelogi Overview.," JIKA (Jurnal Inform., vol. 3, no. 1, pp. 51-58, 2019, doi: 10.31000/jika.v3i1.2045.

[6] E. Bahrudin, A. Sutomo, and U. T. Indonesia, "PEMANFAATAN PLATFORM SOSIAL PADA DAERAH," pp. 66-74, 2021.

[7] A. Dwijayanti and P. Pramesti, "Pemanfaatan Strategi Pemasaran Digital menggunakan E-Commerce dalam mempertahankan Bisnis UMKM Pempek4Beradek di masa Pandemi Covid-19," Ikra-Ith Abdimas, vol. 4, no. 2, pp. 68-73, 2020.

[8] E. Sudarmilah, A. Supardi, and E. A. Muliawan, "Aplikasi Administrasi Laboratorium Pada Rumah Sakit PKU Muhammadiyah Delanggu," J. Emit., vol. 12, no. 01, pp. 8-15, 2012.

[9] T. N. Putri, Rifnaldi, and Surmiyanti, "Penggunaan Bahasa Pemrograman PHP Dan MySQL Sebagai Penunjang Sistem Informasi Persediaan Dan Penjualan Secara Online," vol. 5, no. 2, pp. 61-66, 2019.

[10] N. E. Khomariah, "Implementasi Pemasaran Ikan Hias " Sub Betta Brothers 'Melalui Social Media Dan Digital Marketing,” vol. 2, no. 1, pp. 196-201, 2021, doi: 10.31949/jb.v2i1.674.

[11] W. Erawati, "Perancangan Sistem Informasi Penjualan Dengan Pendekatan Metode Waterfall," J. Media Inform. Budidarma, vol. 3, no. 1, p. 1, 2019, doi: $10.30865 / \mathrm{mib} . v 3 i 1.987$

[12] M. Susilo, "Rancang Bangun Website Toko Online Menggunakan Metode Waterfall," InfoTekJar (Jurnal Nas. Inform. dan Teknol. Jaringan), vol. 2, no. 2, pp. 98-105, 2018, doi: 10.30743/infotekjar.v2i2.171.

[13] N. Cahya and A. Triayudi, "JURNAL MEDIA INFORMATIKA BUDIDARMA Implementasi Framework Codeigniter Pada Perancangan Chatbot Interaktif Menerapkan Metode Waterfall," $J$.
Media Inform. Budidarma, vol. 5, no. 1, pp. 273-279, 2021, doi: 10.30865/mib.v5i1.2623.

[14] I. Essebaa and S. Chantit, "Tool support to automate transformations from SBVR to UML use case diagram," ENASE 2018 - Proc. 13th Int. Conf. Eval. Nov. Approaches to Softw. Eng., vol. 2018-March, no. Lim, pp. 525-532, 2018, doi: 10.5220/0006817705250532.

[15] S. R. Yulistina, T. Nurmala, R. M. A. T. Supriawan, S. H. I. Juni, and A. Saifudin, "Penerapan Teknik Boundary Value Analysis untuk Pengujian Aplikasi Penjualan Menggunakan Metode Black Box Testing," J. Inform. Univ. Pamulang, vol. 5, no. 2, p. 129, 2020, doi: 10.32493/informatika.v5i2.5366.

[16] B. A. Priyaungga, D. B. Aji, M. Syahroni, N. T. S. Aji, and A. Saifudin, "Pengujian Black Box pada Aplikasi Perpustakaan Menggunakan Teknik Equivalence Partitions," J. Teknol. Sist. Inf. dan Apl., vol. 3, no. 3, p. 150, 2020, doi: 10.32493/jtsi.v3i3.5343.

[17] E. Sudarmilah and R. M. P. Siregar, "The usability of 'keepin' collect the trash: Virtual reality educational game in android smartphone for children," Int. J. Eng. Adv. Technol., vol. 8, no. 4, pp. 944-947, 2019.

[18] R. H. Pawestri, H. M. Az-Zahra, and A. N. Rusydi, "Evaluasi Usability Aplikasi Mobile menggunakan Usability Testing dan System Usability Scale (SUS) (Studi Kasus: SOCO, Althea dan Sephora)," J. Pengemb. Teknol. Inf. dan Ilmu Komput., vol. 3, no. 10, pp. 9883-9891, 2019.

[19] I. P. G. Astawa, I. G. M. Darmawiguna, and N. Sugihartini, "Evaluasi Usability Sistem Informasi Kepegawaian Kabupaten Badung (Simpeg Badung) Menggunakan Metode Usability Testing (studi kasus : SMP Negeri 3 Petang)," Kumpul. Artik. Mhs. Pendidik. Tek. Inform., vol. 8, no. 2, p. 209, 2019, doi: 10.23887/karmapati.v8i2.18325.

[20] E. Sudarmilah, M. L. Fatimah, and T. Sagirani, "Digital learning media of surakarta hadiningrat sultanate museum," Int. J. Eng. Res. Technol., vol. 13, no. 12, pp. 4363-4367, 2020. 